\title{
UTILIZATION OF WEED MANURES AND BIOFERTILIZER AS A NUTRIENT SOURCE TO PHASEOLUS AUREUS ROXB.
}

\author{
Chhaya Bhalshankar \\ New Arts Commerce and Science College, Shevgaon, Dist-Ahmednagar, M.S. (India) \\ Corresponding Author: bhalshankarchhaya@gmail.com
}

Communicated: 22.07.2020
Revision :28.07.20 \& 19.8.2020 Accepted: 02.09.2020
Published: 30.09.2020

\begin{abstract}
:
Tephrosia hamiltoni Drumm. and Achyranthes aspera L. are the weed plants grown during rainy season along the road sides and waste land were used to prepare manures like vermicompost, compost as well as neemcake is a residue left after extraction of oil used as nutrient source along with biofertilizer azotobacter and phosphate solubilizing bacteria and only biofertilizer double dose. Treatments given were ATVB, ATCB, NCB, BioD, NPK and control in randomized block design. Growth analysis and yield of grains were studied. Results were shown that highest yield of grains in BioD followed by ATVB, ATCB, NCB, NPK and lowest in control.
\end{abstract}

Key words: -Weeds manures, Neemcacke, Azotobacter, Phosphate solubilizing bacteria.

\section{INTRODUCTION:}

Several studies at the national level have been augmented with the combined use of organic manures, biofertilizers and chemical fertilizers to work out the nutritional formulas that sustains higher yield with least adverse effect on soil and environment. The maintenance of the fertility of the soil is the first condition of any permanent system of agriculture. In the ordinary processes of crop production, fertility is steadily lost; its continuous restoration by means of manuring and soil management is therefore imperative. In maintaining the fertility of the soil, the most careful attention should be paid to the utilization of waste products of agriculture itself and biofertilizers.

Many reports have shown that the interaction between biofertilizers with plant can be beneficial for plant growth and yield (Hazarika et al, 2000; Ratti et al, 2001; Kumar et al, 2002; Darzi et al, 2008; Padmapriya and Chezhiyan 2009).

Microbial inoculation of soil is required for a number of applications, such as plant growth promotion, inhibition of plant pathogens and biodegradation of toxic compounds, soil structure improvement and microbial leaching of metals (Van Veen et al, 1997). Azotobacter vinelandii produces two polymers; the extracellular polysaccharide alginate and the intracellular polyester poly- $\beta$-hydrobutyrate (PHB) (Castaneda et al, 2000). Alginate is important for cyst formation in $A$. vinelandii as a coating protective polysaccharide material (Nunez et al, 1999). It was suggested that cyst formation and colonization pattern play roles in regulating nitrogenase activity of plants (Katupitiya et al, 1995). Plant growth promoting bacteria are becoming the attention of agronomist and microbiologist for their positive role in plant development (Defago and Hass, 1990).

Vermicompost increases the growth rate because of water and mineral uptake such as nitrogen and phosphorus which lead to the biological yield improvement (Atiyeh et al, 2002; Arancon et al, 2004). Karmegam et al. (1999) evaluated germination efficiency, shoot length, roots length, nodulation, weight and yield of green gram (Phaseolus aureus) grown in a 3:1 mixture of 
potting soil and vermicompost cow manure. Germination in vermicompost was $93 \%$ versus 84 $\%$ germination in a control (3:1 mix of potting soil and bio digested manure slurry). Additionally, green gram biomass increased $46 \%$ and shoot height by $28 \%$. Seed pod numbers increased by $35 \%$, pod length increased by $13 \%$ seeds per pod by $20 \%$ and seed yield per plant by $52 \%$.

The present study was emphasized on evaluation of the effectiveness of organic manures prepared from weeds, neemcake and biofertilizers mix with organic manure as well as only biofertilizer in double dose as probable alternative source of nutrients for the yield and nutrient uptake of Phaseolus aureus Roxb. belonging to family Leguminosae an important pulse crop and important part of our daily diet.

\section{METHODOLOGY:}

The experiment was conducted in the college campus of New Arts, Commerce and Science College, Shevgaon, Dist. Ahmednagar during March 2008 to May 2008. The experiment was performed in a randomized block design (RBD) with six treatment and four replicates. Weeds Achyranthes aspera L. and Tephrosia hamiltoni Drumm in 1:1 proportion were used to prepare compost and vermicompost. Weed compost, weed vermicompost and Neem cake were used to study their effectiveness along with biofertilizer (Azotobacter and phosphate solubilizing bacteria) on Phaseolus. All the manures Compost (ATCB), Vermicompost (ATVB) and Neemcake (NCB) (at the rate 9169, 8889 and $1000 \mathrm{~kg} \mathrm{ha}^{-1}$ ) along with biofertilizer Azotobacter and Phosphate solubilizing bacteria at the rate $25 \mathrm{~kg} \mathrm{ha}^{-1}$ (recommended dose) and only Biofertilizer double dose treatment (BioD) $50 \mathrm{~kg} \mathrm{ha-1}$ in two split doses were applied to appropriate plots except chemical fertilizer (NPK) plots. The Mung (Phaseolus aureus Roxb.) Variety "Raj Biotech" Balwan R.J. Biotech, pvt Ltd. Siddharth Arcade, Station Road, Aurangabad was sown in the research plots of size $1.5 \times 1.5 \mathrm{~m}$. at the rate of 20 $\mathrm{kg} \mathrm{ha}{ }^{-1}$. The fertilizers were supplied at the rate of
$25 \mathrm{~kg} \mathrm{~N}, 50 \mathrm{~kg} \mathrm{P}$ and ' $\mathrm{O}$ ' $\mathrm{K} \mathrm{kg} \mathrm{ha}^{-1}$ (25:50:0) only for fertilizer treatment plots. Use of insecticides and pesticides was completely avoided. Growth analysis of crop was done at 31 and 56 (DAS) days after sowing. Pods were collected time to time during growing season. After separation of grains it was kept in oven for analysis of dry matter.

\section{RESULTS AND DISCUSSION:}

Table 1: The First growth analyses of Phaseolus were done at $31^{\text {st }}$ DAS. Height of the plant $(\mathrm{cm}$.) was highest in ATVB (31.98) followed by BioD, ATCB, NPK, NCB and lowest in CON (22.43). The results were statistically significant in all treatments. Circumference was highest in ATVB (1.58) followed by BioD, ATCB, NCB, NPK and lowest in CON (0.98), statistically significant in all treatments except in NPK treatment. The fresh weight and DM of plant was highest in ATVB (7.23, 1.16) followed by ATCB, BioD, NPK, NCB and lowest in the CON (3.05, 0.45), FW was statistically not significant in NCB and NPK, DM was not significant in NCB. Number of branches and leaves was highest in ATCB (4.0, 4.0) followed by ATVB, BioD and NCB, NPK and lowest in CON $(2.75,2.75)$, number of branches and leaves not significant only in NPK. Leaf area was highest in ATVB (54.51) followed by BioD, ATCB, NPK, NCB and lowest in CON (22.38), statistically significant in ATVB, BioD, ATCB.

Table 2: The Second growth analyses of Phaseolus were done at $56^{\text {th }}$ DAS. Height of the plant (cm.) was highest in ATVB (41.43) followed by BioD, ATCB, NCB, NPK and lowest in CON (27.30), statistically significant in all treatments. Circumference was highest in BioD (1.85) followed by ATCB, ATVB, NPK, NCB, and lowest in CON (1.08), statistically significant in all treatments. Number of branches was highest in BioD (14.00) followed by ATCB and NPK, NCB, ATVB and lowest in CON (6.75), number of branches were significant in all treatments. Number of leaves was highest in BioD (24.00)

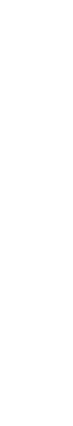

(1) 
followed by ATVB, NPK, ATCB and NCB and lowest in CON (12.00), number of leaves significant in all treatments. Number of Primordia was highest in BioD (10.25) followed by ATVB, NPK, NCB, ATCB and lowest in CON (5.75), number of Primordia significant in all treatments except ATCB. Number of mature legumes of plant was highest in ATVB (5.50) followed by ATCB, BioD, NCB, NPK and lowest in the CON (2.50), statistically significant in all treatments except in NPK. Number of immature legumes of plant was highest in ATCB (5.00) followed by NPK, BioD, ATVB, NCB and lowest in the CON (0.25), statistically significant in all treatments. Leaf area was highest in BioD (108.61) followed by ATVB, ATCB, NPK, NCB and lowest in CON (41.55), statistically not significant in NCB and NPK treatments. Stefan et al (2010) stated that inoculation of soybean by Bacillus pumilus significantly increased plant height, leaf number, leaf area, grain protein and nodulation.

Table 3: Analyses of fresh and dry matter yield of legumes, grains and shells

FW of legumes (gm plot-1 and $\mathbf{~ g h ~ h a}^{-1}$ ) recorded highest in ATVB $(260.48,1158)$ followed by ATCB, BioD, NCB, NPK and lowest in CON (165.77, 737), statistically not significant in NPK treatments. FW of grain (gm plot ${ }^{-1}$ and $\mathrm{kg} \mathrm{ha}^{-1}$ ) recorded highest in BioD $(163.28,726)$ followed by ATVB, ATCB, NCB, NPK and lowest in CON $(106.65,474)$. DM of grains recorded highest in BioD followed by ATVB, ATCB, NCB, NPK and lowest in CON, statistically not significant in NPK treatments. FW of shell (gm plot-1 and $\mathbf{~ k g ~ h a}^{-1}$ ) recorded highest in ATVB (99.21, 441) followed by ATCB, NCB, BioD, NPK and lowest in CON $(59.12,263)$. DM of shell recorded highest in ATCB followed by ATVB, NCB, BioD, NPK and lowest in CON statistically not significant in NPK treatments

\section{CONCLUSION:}

It is concluded from the present investigation that Biofertilizer double dose, weed vermicompost, weed compost and neem cake along with single recommended dose proved better to increase yield of the crop as compare to chemical fertilizer, and reducing the input cost of the farm produce along with protection of the environment and natural resources.

\section{REFERENCES:}

Hazarika, D. K., Talukdar, N. C., Phookan, A. K., Saikia, U. N., Das B. C., Deka, P. C. (2000). Influence of vesicular arbascular mycorrhizal fungi and phosphate solubilizing bacteria on nursery establishment and growth of tea seedlings in assam. Symposium No.12, Assam Agricultural University, Jorhat-Assam, India.

Ratti, N. Kumar S., Verma, H. N. Gautam, S. P. (2001). Improvement in bioavailability of tricalcium phosphate to cymbopogon martini var.motia by rhizobacteria. AMF and Azospirillum inoculation. Microbiol Res., 156:145-149.

Kumar, S. Choudhary, G. R., Chaudhari, A. C. (2002). Effects of nitrogen and biofertilizers on the yield and quality of coriander (Coriandrum sativum L.) Ann. Agr.Res., 23(4):634-637.

Darzi, M.T., Ghalavand, A., Rejali, F. (2008). Effect of mycorrhiza, vermicompost and phosphate biofertilizer application on flowering, biological yield and root colonization in fennel (Foeniculum vulgare Mill.). Iran. J. Crop. Sci., 10(1): 88-109.

Padmapriya, S., Chezhiyan, N. (2009). Effect of shade, organic, inorganic and biofertilizers on morphology, yield and quality of turmeric. Indian J.Hort.,66 (3): 333-339.

Van Veen, J. A., Overbeek, L. S., Van Elas ,J. D. (1997). Fate and activity of microorganism's introduction into soil. Microbiol. Mol. Biol. Rev., 61: 121-135.

Castaneda, M., Guzman, J., Moreno, S., Espin, G. (2000). The GacS sensor kinase regulates 
alginate and poly-ß-hydro butyrate production in Azotobacter vine landii. J. Bacteriol., 182: 2624-2628.

Nunez, C., Moreno, S., Soberon-Chavez, G., Aspin, G. (1999). The Azotobacetr vine landii resonse regulator AlgR is essential for cyst formation. J. Bacteriol., 181: 141148.

Katupitiya, S., Miller,J., Vesk, M., Viccars, L., Zeman, A., Lidung, Z.,Elmerich, C., Kennedy I.R. (1995). A mutant of Azospirillum brasilense Sp 7 impaired in flocculation with a modified colonization pattern and superior nitrogen fixation in association with wheat. Appl. Environ. Microbiol., 61: 1987-1995.
Defago, G., Hass, D. (1990). In: Soil Biochemistry (Bollag JM, Stotzky G eds), Deker, New York, 6: 249.

Atiyeh, R.M., Arancon, N., Edwards, C.A., Metzger, J.D. (2002). The influence of earthworm- processed pig manure on the growth and productivity of marigolds. Bioresource Technol., 81: 103-108.

Arancon, N., Edward, C.A., Bierman, P., Welch, C., Metzger, J. D. (2004). Influence of vermicomposts on field strawberries: 1 . Effect on the growth and yields. Bioresources Technol., 93: 145-153.

Karmegam, N., Alagermalai, K. and Daniel, T. (1999). Effect of Vermicompost on the growth and yield of green gram (Phaseolus aureus Roxb.). Tropical Agriculture 76(2):143-146. 
I J R B A T, Issue (VIII), Vol. III, Sept 2020: 118-122

A Double-Blind Peer Reviewed \& Refereed Journal

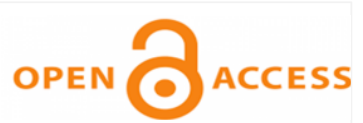

e-ISSN $2347-517 X$

Table1: Growth analyses of Phaseolus (at 31 DAS)

\begin{tabular}{lcccccccc}
\hline Treatment & Height & Circumference & Plant wt in gm & $\begin{array}{c}\text { No. of } \\
\text { Branches }\end{array}$ & $\begin{array}{c}\text { No. of } \\
\text { Leaves }\end{array}$ & $\begin{array}{c}\text { No.of } \\
\text { Primordia }\end{array}$ & $\begin{array}{c}\text { Leaf } \\
\text { area } \\
\text { (cm2) }\end{array}$ \\
\cline { 2 - 5 } & $\mathbf{( c m )}$ & $\mathbf{( c m )}$ & FW & DM & & & & \\
\hline ATVB & 31.98 & 1.58 & 7.23 & 1.16 & 3.75 & 3.75 & 1.00 & 54.51 \\
ATCB & 28.18 & 1.38 & 6.25 & 0.97 & 4.00 & 4.00 & 1.00 & 42.73 \\
BioD & 30.70 & 1.53 & 5.88 & 0.87 & 3.25 & 3.25 & 1.00 & 52.47 \\
NCB & 25.48 & 1.20 & 4.03 & 0.62 & 3.25 & 3.25 & 1.00 & 26.02 \\
NPK & 27.38 & 1.08 & 4.24 & 0.70 & 3.00 & 3.00 & 1.00 & 32.41 \\
CON & 22.43 & 0.98 & 3.05 & 0.45 & 2.75 & 2.75 & 1.00 & 22.38 \\
\hline S.E & 1.42 & 0.10 & 0.65 & 0.11 & 0.19 & 0.19 & 0.00 & 05.54 \\
C.D. & 3.02 & 0.21 & 1.38 & 0.22 & 0.40 & 0.40 & 0.00 & 11.80 \\
\hline
\end{tabular}

ATVB=Achyranthes, Tephrosia vermicompost with Biofertilizer, ATCB=Achyranthes, Tephrosia compost with biofertilizer, BioD=Biofertilizer double dose, $\mathrm{NCB}=\mathrm{Neem}$ cake along with biofertilizer.

Table2: Growth analyses of Phaseolus (at 56 DAS)

\begin{tabular}{|c|c|c|c|c|c|c|c|c|}
\hline \multirow[t]{2}{*}{ Treatment } & \multirow{2}{*}{$\frac{\text { Height }}{(\mathrm{cm})}$} & \multirow{2}{*}{$\frac{\text { Circumference }}{(\mathrm{cm})}$} & \multirow[t]{2}{*}{$\begin{array}{c}\text { No. Of } \\
\text { Branches }\end{array}$} & \multirow[t]{2}{*}{$\begin{array}{c}\text { No. of } \\
\text { Leaves }\end{array}$} & \multirow[t]{2}{*}{$\begin{array}{c}\text { No. of } \\
\text { Primordia }\end{array}$} & \multicolumn{2}{|c|}{ No. of legumes } & \multirow{2}{*}{$\frac{\text { Leaf area }}{\mathrm{cm} 2}$} \\
\hline & & & & & & Mature & Immature & \\
\hline ATVB & 41.43 & 1.78 & 11.50 & 19.50 & 09.00 & 5.50 & 3.50 & 106.93 \\
\hline ATCB & 34.53 & 1.80 & 12.50 & 18.00 & 06.75 & 5.25 & 5.00 & 069.09 \\
\hline BioD & 37.23 & 1.85 & 14.00 & 24.00 & 10.25 & 4.75 & 4.25 & 108.61 \\
\hline $\mathrm{NCB}$ & 33.23 & 1.45 & 11.75 & 18.00 & 07.75 & 4.25 & 3.00 & 053.55 \\
\hline NPK & 32.10 & 1.70 & 12.50 & 18.75 & 08.50 & 3.00 & 4.50 & 062.16 \\
\hline $\mathrm{CON}$ & 27.30 & 1.08 & 06.75 & 12.00 & 05.75 & 2.50 & 0.25 & 041.55 \\
\hline$\overline{\text { S.E }}$ & 1.95 & 0.12 & 1.01 & 1.57 & 0.66 & 0.50 & 0.70 & 11.40 \\
\hline C.D. & 4.15 & 0.26 & 2.15 & 3.34 & 1.40 & 1.06 & 1.48 & 24.28 \\
\hline
\end{tabular}

Table:3 Fresh weight and Dry Matter analysis of legumes, grains and shell

\begin{tabular}{|c|c|c|c|c|c|c|c|c|}
\hline \multirow[t]{2}{*}{ Treatment } & \multicolumn{2}{|c|}{$\begin{array}{c}\text { Fresh wt. of } \\
\text { legumes }\end{array}$} & \multicolumn{2}{|c|}{ Fresh wt. of grains } & \multirow{2}{*}{$\frac{\text { DM }}{\text { Kg hect }^{-1}}$} & \multicolumn{2}{|c|}{ Fresh wt. of shells } & \multirow{2}{*}{$\begin{array}{c}\text { DM } \\
\text { Kg hect-1 }^{-1}\end{array}$} \\
\hline & $\begin{array}{c}\text { gm } \\
\text { plot-1 }\end{array}$ & $\begin{array}{c}\text { Kg } \\
\text { hect-1 }\end{array}$ & $\begin{array}{c}\text { gm } \\
\text { plot-1 }\end{array}$ & Kg hect-1 & & gm plot-1 & Kg hect-1 & \\
\hline ATVB & 260.48 & 1158 & 161.27 & 717 & 681 & 99.21 & 441 & 318 \\
\hline ATCB & 244.50 & 1087 & 145.44 & 646 & 609 & 99.07 & 440 & 319 \\
\hline BioD & 241.97 & 1075 & 163.28 & 726 & 682 & 78.86 & 350 & 259 \\
\hline NCB & 228.69 & 1016 & 136.44 & 606 & 561 & 92.25 & 410 & 297 \\
\hline NPK & 185.01 & 0822 & 123.90 & 551 & 521 & 61.11 & 272 & 193 \\
\hline $\mathrm{CON}$ & 165.77 & 0737 & 106.65 & 474 & 443 & 59.12 & 263 & 191 \\
\hline $\mathrm{SE}$ & 15.20 & 67.70 & 08.96 & 39.80 & 38.30 & 07.44 & 33.00 & 24.10 \\
\hline $\mathrm{CD}$ & 32.38 & 144.20 & 19.08 & 84.77 & 81.58 & 15.85 & 70.29 & 51.33 \\
\hline
\end{tabular}

